\title{
French Legal System in Puducherry vis-a-vis the Hindu law in India: Impact on Women and Children
}

\author{
Vayuna Gupta*
}

\section{Abstract}

The French acquired the territory of Puducherry in 1963 and since then a major quantum of the Puducherry legal system derives influence from the legal system of France. Post-independence, the citizens of this union territory were given an option to choose to be governed by either the French Law or the Indian Law. A few striking differences exist between these two legal systems with respect to adoption, marriage and divorce caused due to irretrievable breakdown of marriage. The French law defines 18 as the minimum age of marriage irrespective of sex, while Indian law provides for a minimum age of 18 and 21 for woman and man respectively. Additionally aspects such as consent in marriages and declaring marriage null and void are very different as per the jurisprudence of both systems. The Hindu Law does not provide for irretrievable breakdown of marriage, though recommendations have been made by the $217^{\text {th }}$ Law Commission in 2009. These recommendations seem to be more feasible compared to the French Laws. Unlike the French law on adoption, earlier under Hindu law a woman could not adopt a child without relating the child to her husband. In such conditions divorced women faced difficulties during the process of adoption. Despite being a more progressive society, application of a few French Laws may not be consistent with the social conditions of

* Second Year, BA, LLB (Hons.), National Law School of India University, Bangalore; vayunasunilgupta@nls.ac.in. 
our nation. It shall not be incorrect to conclude that it is extremely essential to mould these foreign laws to fit into the Indian society and survive therein.

Keywords: Adoption, French Legal System, The Hindu Adoptions and Maintenance Act 1956, Hindu Law, Irretrievable Breakdown of Marriage.

\section{Introduction}

The Indian legal system has been greatly influenced by the legal systems and the laws that governed the colonial rulers. Certain Indian laws have been drafted either by the colonial rulers themselves (For instance, The Indian Penal Code, 1860) or by committees constituted by them (For instance, The Constitution of India, 1950). The territory of Puducherry, was acquired by the French in 1673. The French laws of Puducherry (hereinafter French Law/s) were substantially enforced in the area and a remarkable difference in the judicial system is being witnessed as opposed to the legal system followed in the rest of the country. An insightful reasoning is required to compare and contrast the laws applicable in Puducherry with the rest of the country. These laws serve as an example of the successes or failures of supplanting foreign regulations in India.

The researcher aims to give a broad idea of the French Law in Puducherry. This paper will introduce the idea of 'French India', the transfer of power by the French to the Government of India and the modifications made to cater to the specific needs of the people considering their distinct culture and identity. The main objective of the paper is to compare certain provisions of family law under the French legal system with those under Hindu law. The comparison shall be made from a critical point of view. Primarily, a feminist perspective will be adopted for this purpose. The following questions shall be answered in the course of the study:

1. Why is the French legal system prevalent in Puducherry?

2. Which provisions under French law are different from those under Hindu law? 
3. Are the provisions under French Law beneficial or detrimental for women and certain other sections of the society?

In this article, the authors would address some of the differences in the French and Indian marriage laws, divorce on the grounds of irretrievable breakdown of marriage laws and adoption laws to study their scope and limitation on the rights of women. The researcher shall conclude by studying the implications of adoption of foreign laws in India.

\section{Development of the Legal System in Puducherry}

The union territory of Puducherry comprises the French settlements in the then Pondicherry, Karaikal (Tamil Nadu), Mahe (Kerala) and Yenam (Andhra Pradesh). The French acquired it in 1673 and since then it had been governed by French law and personal laws in accordance with the customs followed in Paris. By the resolution dated January 6, 1819 all the French codes except the Code of Criminal Procedure were made applicable to the territory of Puducherry. Section 3 of the resolution made an exception for the Hindus, Muslims and Christians according to which they could choose to be governed by their own customary practices. ${ }^{1}$ But if, by clothing and customs any individual had accepted the French way of life then, French law was applicable to him. This was termed by the courts as tacit renunciation of a personal status. ${ }^{2}$ Renunciation could also be initiated in the presence of the Registrar of the civil courts or under the resolution dated September 21, 1881 as well. People were incentivised to do so. Primarily people belonging to the minority religions like Christianity in India gave in to this incentive. These people were termed as 'Renoncants' and till date

1 J.A.S Cordeno, Legal Cultural and Legal Transplants, 2010, International Academy of Comparative Law,Report to the XVIIIth Conference of Comparative Law, available at: http://isaidat.di.unito.it/index.php/isaidat/article/viewFile/41/47 (last visited on Jul. 10, 2014).

${ }^{2} I d$. 
French law applies to them for purposes of marriage, divorce and other family matters. ${ }^{3}$

The territory of Puducherry was taken by the Government of India de facto on November 1, 1954 and the French Establishment Order, 19544 extended the application of laws specified in the schedule to the French Establishments Order. Till the implementation of this law the de jure transfer of French establishments was carried out in Puducherry. The Treaty of Cession was signed between India and France which promised to ensure that the French population would be protected in India and the renoncants would be governed by the French Civil Code. ${ }^{5}$ Certain laws relating to marriage, divorce under irretrievable breakdown of marriage and adoption under the French Legal System are analyzed and compared with Hindu Law in the subsequent paragraphs.

\section{Marriage under the Hindu Law and the French Legal System}

The Hindu Marriage (Pondicherry) Amendment Act was passed in 1971. It amended Sec. 2 of The Hindu Marriage Act, 1955 to exclude Renoncants from any of the provisions in the Hindu Marriage Act. Sec. 7 was amended to include suyamariyathai and seerthirutha marriages.

As per Sec. 7-A such marriages were acceptable in the eyes of law merely by the exchange of garlands or rings or vows taken in a language understood by both the parties. The presence of the priest was not necessary for the performance of the marriage. ${ }^{6}$ This is remarkably different from the Hindu marriage laws in the rest of the country where for solemnizing a marriage under the Hindu Marriage Act customary rights and ceremonies are important. ${ }^{7}$ As

\section{${ }^{3}$ Supra note 1.}

4 (By virtue of an agreement between Government of India and Government of France, the Central Government had jurisdiction in relation to French Establishments in India).

${ }^{5}$ Supra note 1.

6 K. Desai, Indian LAW of Marriage AND Divorce 123 (Lexis Nexis Butterworths Wadhwa Nagpur, $6^{\text {th }}$ edn. , 2011).

${ }^{7}$ Hindu Marriage Act, 1955, § 7. (In A.N. Mukherjee v. State, it was held that marriages not performed according to ceremonial rituals as 
against the general practice in India where the family of the bride is expected to incur huge expense and sometimes debts either due to demand from the groom's family or as a display of their status in the society. In Suyamariyathai and Seerthirutha marriages incurring of such unnecessary expense is not encouraged and the consensual agreement to engage them in a bond is demarked as requisite enough for a marriage.

For the renoncants governed by the French law the minimum age for marriage is 18 for both the spouses. ${ }^{8}$ The Prohibition of Child Marriage Act 2006: specifies that a girl cannot marry before 18 years and a boy before 21 years. ${ }^{9}$ We can see that carrying forward the tradition of a patriarchal society; this provision is somewhere based on the age old custom that men should be elder than women at the time of their marriage. Thus, the Indian law on eligible age to marry is a complete reflection of patriarchy and gender injustice while the French law provides an equal footing for both the genders.

French marriages are neither sacraments nor contracts, rather they are celebrated by officer de l'etat civil at the place where one of the parties resides or has been domiciled at least for one month before the marriage. ${ }^{10}$ As per Hindu law a marriage is majorly a sacrament, it is a sanskar. It serves two purposes: (i) performance of yojna. (ii) Creation of sexual affinity. ${ }^{11}$ The fact that Hindu marriages are sacraments can be substantiated if we try to analyze the status granted to marriages in recent times too. The essentials of a Hindu marriage ceremony include a Brahmin performing the rituals in front of the sacred fire, the bride and the groom taking seven pheras round the holy fire signifying that they shall be tied in an eternal bond for seven generations. Unless the marriage is

mentioned in the Hindu Marriage Act will not be considered as a marriage at all).

${ }^{8}$ D. ANNOUSSAMY, THE FRENCH LEGAL SYSTEM 244 (2nd edn,. 2011).

${ }^{9}$ (The Hindu marriage Act does not have any clause specifying any bar on age for marriages).

10 D. Annoussamy, supra note 8, at 246.

${ }^{11} \mathrm{~K}$. DESAI, supra note 7 , at 117. 
celebrated or performed as per ceremonies in its due form it cannot be said to be solemnized.12 Marriage is showcased as a spiritual and moral obligation which should be adhered to in all circumstances. Thus a lot of women choose to live a distorted life in their marriage homes because they do not want to break this 'sacred bond'. Those who are courageous enough and manage to break the 'sacred bond' are either condemned or ostracized by the society and blamed for being morally incorrect at the very least. This is a strong social disincentive for women alongside the fact remains that they have been forced into believing in the sanctity of the marriage and it being a sin to break it. The inception of all these preaching is founded on the fundamental belief that marriages are sacraments. Many have recently argued that the growing trend of divorces has forced them to view marriages as contracts. But according to the author the Hindu Marriage Act, 1955 majorly looks at marriage as a sacrament which ties the woman into an unbreakable bond. The author believes that marriage as a sacrament or even as a contact shall create a greater obligation on individuals to adjust in the marriage. However it is never disputed that the obligations should be equal for both the spouses. This is not to suggest that marriages in their worst phase should be protected too but only that they should be held on to until possible.

Under French Law, social recognition of marital status is not enough to recognize a marriage. ${ }^{13}$ Factors such as under-age ${ }^{14}$, absence of consent, absence of one or both the parties to be married, polygamy and marrying within a prohibited degree of relationship can render a marriage void 15 . Under the Hindu Marriage Act, 1955 marriages entered into by misrepresentation of one of the spouses, or within a prohibited degree or within the same sapindas are declared as void. But it does not talk about the

12 D.F. Mulla, Hindu LAW 864 (Lexis Nexis, 21 ${ }^{\text {st }}$ edn.,2013).

${ }^{13}$ D. ANNOUSSAMY, supra note 9 , at 248.

14 (The minimum age for marriage for both the spouses is 18. D. Annoussamy, supra note 9, at 244).

15 (A void marriage is not a marriage, it is a marriage that does not exist since the beginning). P. DIWAN, LAW OF MARRIAGE AND DivORCE 225 (Universal Law Publishing, $6^{\text {th }}$ edn., 2011). 
age of the parties. It is not disputed that The Prohibition of Child Marriage Act, 2006 lays a ban on the minimum marriageable age but, the Hindu Marriage Act continues to remain silent on it. All Hindu marriages are solemnized under the Hindu Marriage Act. Consent is also a major factor of difference between the French and the Indian Law. As per the Hindu Marriage Act, consent obtained via force ${ }^{16}$ or due to the mental disability of one of the parties for marriage renders it voidable17. Now the major question here is of 'force' and its forms in India. Force in Indian context never was and never will be force per se, as traditionally women in our country are taught to abide by the decisions taken by their parents since childhood,. This effectively constrains a girl from making her own decisions during marriage. In certain cases there may be a presence of force, in its literal sense, yet women do not raise their voices because they have been taught to always follow the decisions of the elders or they do not want to go against the wishes of their parents who have nurtured them. An example for the same can be when rape victims are married off to the rapists themselves against their will. Force does not mean torturing, black mailing etc. but it is a pressure which has become a part of societal preaching in the Indian scenario. Thus, though the section may provide for a voidable marriage on account of force, it fails to consider these aspects of the Indian society and hence is rendered toothless in most circumstances. Also, any such marriage where consent is obtained via force is voidable only at the discretion of one of the parties, but as explained, the woman shall never actively take steps to do so. But, it is also true that in order to achieve congruence with the French Law if such marriage where consent is obtained via force is declared as void it shall serve no purpose, except for depriving a woman of her marital status post the long years spent with her husband. Thus, consent under coercion as the basis to render a marriage void is more suitable in the Indian context. But

${ }^{16}$ The Hindu Marriage Act, 1955, § 12(1)(c).

17 (A voidable marriage is the one that will be regarded by every court as a valid subsisting marriage until a decree annulling it has been passed by one of the competent jurisdictions). P. DIWAN, supra note 16, at 226. 
from a different perspective, under French Law a mere absence of consent renders the marriage void, which has a wider application as against the Hindu law where consent only via force is voidable. One such example could be consent obtained through misrepresentation by her own family members might not fall under the category of consent obtained via force.

\section{Irretrievable Breakdown of Marriage}

The 217th Law Commission report ${ }^{18}$ stated that the courts do not have to deal with ideal husbands and ideal wives; instead they have to deal with a particular man and woman. Hence conditions might arise where the couple due to personal reasons and circumstances is not able to adjust and hence cohabit. Irretrievable breakdown of marriage means that the marriage has broken down beyond repair and there is absolutely no way that such a marriage can be revived. The test for consenting to an irretrievable breakdown of marriage is to see whether the partners would have reconciled if divorce was not granted. ${ }^{19}$ Upon such a disposition it can be taken to assume that the marriage has broken down beyond repair. Divorce on such grounds is also known as no fault divorce. ${ }^{20}$

As per French Law, a spouse may file for divorce on the basis of prolonged breakdown in common life after a minimum separation period of six years or some mental disability inflicted upon the spouse such that living together becomes impossible. ${ }^{21}$ Despite this, the judge has the freedom to reject the divorce if he believes that it shall cause extreme harshness to either the children or either of the spouse. ${ }^{22}$ When the case for irretrievable breakdown of marriage

18 217th Law Commission Report, Irretrievable Breakdown of MarriageAnother Ground for Divorce, p. 10, (2009).

19 B. McKenna, Divorce by Consent and Divorce by Breakdown of Marriage, 30(2) WiLEY: THE MODERN LAW REVIEW 121, (1967).

$2071^{\text {st }}$ Report of the Law Commission of India, Irretrievable Breakdown of Marriage as a Ground for Divorce, p.14, (1978). (It is called a no fault divorce since ajority of the divorces are granted on the basis of matrimonial fault.Such as adultery, bigamy, cheating etc.)

21 D. ANNOUSSAMY, supra note 9, at 256.

${ }^{22} \mathrm{I} d .$. 
starts, the spouse is free to file a counter petition for divorce on different grounds. ${ }^{23}$

As per the Hindu Marriage Act, 1955 there is no explicit provision for granting divorce on account of irretrievable breakdown of marriage. The $71^{\text {st }}$ Law Commission Report recommended certain amendments to Sec. 13 of the Hindu Marriage Act for the same. ${ }^{24}$ But judges in various cases have been observed to give decisions on the basis of irretrievable breakdown by relying upon Sec. 13 of the Hindu Marriage Act. ${ }^{25}$ According to this when there has been no cohabitation between the spouses after a period of one year of passing a decree of judicial separation or for the restitution of conjugal rights, divorce can be demanded for. ${ }^{26} \mathrm{~A}$ person filing for irretrievable breakdown of marriage will be able to end the marriage only after the consent of his spouse. The period of one year begins from the day the proceeding in the trial court begins and not the appellate court.27 The Marriage Laws (Amendment) Act, 1976 reduced the period of two years (earlier) to one year.

Earlier, divorce on these two grounds was obtained due to noncompliance with the judicial orders but in 1964 as per a private member's bill they were converted into the grounds of irretrievable breakdown of marriage. In Naveen Kohli v. Neelu Kohlize the judges for the first time recommended the legislature to consider irretrievable breakdown of a marriage as a strong contention for divorce.

\section{${ }^{23} \mathrm{Id}$. at 257.}

${ }^{24}$ Supra note 20. (A marriage shall be irretrievably broken down when the parties have lived separately for a period of 3 years before the petition is initiated. The term 'living separately' shall include only conditions when they have not been living in the same household. Though there shall be caveat that if the court believed that this shall result in great financial hardship to the other spouse then the divorce shall not be granted. Also, it was proposed that 23(1)(a) shall not affect the given section whatsoever).

${ }^{25}$ Geeta Mullick v. Brojo Gopal Mullick, A.I.R. 2003 Cal. 321.

${ }^{26}$ The Hindu Marriage Act, 1955, §13(1-A).

${ }^{27}$ P. DIWAN, supra note 16 at 500 .

${ }^{28}$ Naveen Kohli v. Neelu Kohli, A.I.R. 2006, S.C. 1675. 
Courts on occasions have erred in including disinclination of reunion under Sec. 23(1)(a) and denying the relief which either the husband or the wife is entitled to. As per Justice A.C. Gupta,

In order to be a wrong within the meaning of section 23(1)(a), the conduct has to be something more than mere disinclination to agree to an offer of reunion, it must be misconduct serious enough to justify denial of the relief to which the husband or the wife is entitled. ${ }^{29}$

Except for the fact that there is no explicit section under Hindu Law to consider irretrievable breakdown of marriage as a contention for divorce there are two other major points of difference in the recommendations by the $71^{\text {st }}$ Law Commission report and the French law . Firstly, under the French law, a separation of minimum six years is required to file for divorce. This seems too long a period for beginning the proceedings on irretrievable breakdown. In such cases ordinary Indian women will be socially ostracized and/or face economic hardships due to this long separation. ${ }^{30}$ Stipulating anyone to live alone for so long in order to initiate legal separation is incorrect, thus, the recommendation by the Law Commission for a period of three years seems more feasible. There is a basic requirement to adjust in a marriage and certain minimum time period is required for the same. A period of three years is requisite enough for the couple to judge the status of their relationship. Secondly, as per French law no decree of divorce shall be given due to irretrievable breakdown if it shall cause grave 'hardship' to the other spouse. On the other hand The Law Commission Report takes into account only 'financial hardships'. This is inadequate because sometimes there is a deep emotional attachment of the children towards their parents and such separation might lead to negative consequences. Also, it is important for the Law Commission to consider the hardships faced

${ }^{29}$ Dharmendra Kumar v. Usha Kumar, A.I.R. 1977 S.C. 2218.

30 (In addition though women can claim maintenance there is no provision for a share in the husband's property. This is one major reason for the opposition of irretrievable breakdown of marriage by women's organisations). 
by both the children and the spouse after the relationship ends. Another factor being that there is no definition provided for this financial hardship can lead to extremely subjective interpretations by courts and the petitioners.

\section{Adoption under the Hindu Law and the French Legal System}

As per French laws a Hindu widow could adopt a child and similar was the case with a French widow domiciled in French India also. The rights to succession for these adopted children were held in the case of C.S. Natarajan Pillai v. C.S. Subbaraya Chettair ${ }^{31}$.The widow was domiciled in French India i.e. Puducherry and the adopted son was a domicile of Madras. The domicile of the mother permitted her to adopt a child with or without her husband's consent, and the child would have the complete right to inherit her mother's and also her deceased father's property. However as per the prevailing law in Madras ${ }^{32}$ a woman could adopt a child only after the appropriate consent of her husband and only then he shall be identified as the son of her husband under law. When a woman died, the French courts notwithstanding the fact of lex loci res sitae ${ }^{33}$ granted the possession of the woman's property in Puducherry to her son. But the Madras court did not agree to do so primarily because the adoption by his father was disputed, and the lex situs governed the immovable property. The major derivations from this case were that the lex situs should include the foreign law of the last domicile of the propstius and heir to the immovable property should not be determined. If the person adopting has the right to adopt according to his own lex domicile the status of the adopted child can be created without reference to the law of the domicile of the adoptee prior to adoption. Thus in the French legal system rights were given to women to adopt children based upon their

${ }^{31}$ C.S. Natarajan Pillai v. C.S. Subbaraya Chettair, A.I.R. 1949 P.C. 34.

32 (Madras was then under British rule and hence British law applied).

33 (Lex loci res sitae is latin for the law of the place where the property is situated). 
own discretion and these adopted children had all the right to inherit their mother's property too. ${ }^{34}$

The Hindu Adoptions and Maintenance Act, $1956^{35}$ marked a great difference in the Indian succession laws. Before 1956 a Hindu widow could not adopt a child since she acted as an agent of the Hindu man for procuring a son and the main purpose of the son was to continue with the family lineage of the father. After the Act was passed, the widow could adopt for herself and did not need the permission of her husband's sapindas and the child was considered as that of the late husband's as well. This was referred to as the doctrine of 'Relating Back'. ${ }^{36}$ This made it impossible for divorced women to adopt children and start their life afresh if they wished to. Also, a son adopted by a Hindu widow could be the coparcener as others with all the rights and liabilities of a coparcener. ${ }^{37}$ But the adopted son could not divest the heir of the property of the collaterals. ${ }^{38}$ Thus we see that French law in the territory of Puducherry was a little more gender neutral and gave equal rights to women for adoption. , Comparatively, the Hindu law permitted widows to legally adopt in India after the enactment of the Hindu Adoptions and Maintenance Act, 1956.

\section{Conclusion}

The Hindu law in the aforementioned fields and specific respects has to undergo a lot of changes to cater to the requirements of women as the French law does. But this is not to put forth that French law shall suit our country's historical and cultural background always. The researcher sincerely believes that the

34 J.D.M Jurrett, Private International Law Adoption, 20(1) WILEY THE MODERN LAW REVIEW, 65, 67 (1957).

35 The Hindu Adoptions and Maintenance Act, 1956, §8.

36 S.E. Thomas, Gender and Hindu Adoption law in India in Essays in family law in memory of B N Sampath Vol. II : Gender, Human Rights and Law, 19, 25, (S.E. Thomas ed.,2013).

37 G.V.C.S RAO, FAMILY LAW IN INDIA 248 (Narender Gogia \& Company, 10th edn., 2011).

${ }^{38} \mathrm{Id}$. 
French law in Puducherry has an upper hold in contrast to the Indian law in a lot of cases. These include the wide application of the term 'hardship' in irretrievable breakdown of marriage law, 'absence of consent' rendering a marriage void, adoption by widows and the complete rights of the adoptee to the property of the widow as well as her late husband but as far as the solemnization of the marriage is concerned, Hindu marriages as sacraments are more forceful and encouraging.

Thus, though any legal system might borrow from another legal system, it is essential that the laws are modified to suit the needs of the country. Section 3 of the French Civil code and Section 2 of the Hindu Succession (Amendment) Act, 2005 are examples of the same. Family law as a system of law must function in consonance with historical and customary traditions of the place before enacting laws since they play a vital role in ensuring their acceptance. If there is no agreement for the same and such laws are enforced simply due to their successful execution in a foreign land it shall lead to either chaos or revolt. Since Puducherry has been governed by the French for a long period and French laws have been followed, continuation of the same can be considered reasonable and quintessentially this is the reason for the acceptance of French law in Puducherry at present. Thus, the researcher concludes that the acceptance of the idea of marriage as a civil ceremony shall be tough to execute in India whereas the definition of hardship as under French irretrievable breakdown of marriage law when accepted, under Indian Hindu law, shall increase its scope remarkably. Thus, to conclude foreign laws should be viewed critically and accepted rationally for any territory, for which Puducherry is a noteworthy example. 